\title{
Carbon Sequestration through Reforestation: An Effective Measure to Mitigate the Climate Change
}

\author{
Vinod Kumar*
}

Agro-ecology and Pollution Research Laboratory, Department of Zoology and Environmental Science, Gurukula Kangri University, Haridwar-249404 (Uttarakhand), India

*Corresponding Author: Kumar, V. Agro-ecology and Pollution Research Laboratory, Department of Zoology and Environmental Science, Gurukula Kangri University, Haridwar-249404 (Uttarakhand), India; E-mail: drvksorwal@gkv.ac.in

\section{Introduction}

Before the industrial revolution, the concentration of greenhouse gases (GHGs) in the atmosphere remained relatively constant. Except for slow changes on a geological time scale, the absorption and release of carbon was kept in balance. During that time, changes in biomass and soil organic carbon were the main sources of fluctuation in atmospheric levels of carbon. Carbon is found in all living organisms and is the major building block for life on earth. Carbon exists in many forms, predominately as plant biomass, soil organic matter, and as the gas carbon dioxide $\left(\mathrm{CO}_{2}\right)$ in the atmosphere and dissolved in seawater. Carbon sequestration is the long term storage of carbon in oceans, soils, vegetation (especially forests), and geologic formations. Although, oceans store most of the earth's carbon, soils contain approximately $75 \%$ of the carbon pool on land three times more than the amount stored in living plants and animals. Therefore, soils play a major role in maintaining a balanced global carbon cycle. By clearing forests and burning fossil fuels more rapidly than the carbon can be sequestered, industrialization may have altered this equilibrium. Currently, human activity is directly or indirectly responsible for the release of six to seven billion metric tons of carbon annually. Since before the industrial revolution, $\mathrm{CO}_{2}$ concentrations in the atmosphere have increased from 280 parts per million (ppm) to nearly $380 \mathrm{ppm}$ in 2005. The $\mathrm{CO}_{2}$ emissions from energy use are projected to increase between 40 to 110 percent between 2000 and $2030^{[1-3]}$.

\section{Basic concepts of carbon sequestration}

Atmospheric enrichment of GHGs can be moderated by either reducing anthropogenic emissions, or sequestering $\mathrm{C}$ in plant biomass or the soil. Transfer of atmospheric $\mathrm{CO}_{2}$ into other pools with a longer MRT, in such a manner that it is not re-emitted into the atmosphere in the near future, is called sequestration. Depending on the processes and technological innovations, there are three main types of $\mathrm{C}$ sequestration: (i) those based on the natural process of photosynthesis and conversion of atmospheric $\mathrm{CO}_{2}$ into biomass, soil organic matter or humus and other components of the terrestrial biosphere; (ii) those involving engineering techniques; and (iii) those involving chemical transformations ${ }^{[2,3]}$.

\section{Types of sequestration}

Sequestration encompasses all forms of carbon storage. Oceans, plants and underground geologic formations all function as significant reservoirs for $\mathrm{CO}_{2}$. They all exchange $\mathrm{CO}_{2}$ with the atmosphere. These reservoirs will act as carbon sinks if more carbon is flowing into them (or stored in them) than flows out of them. Three primary categories describe the primary types of sequestration. Terrestrial sequestration: It is a form of indirect sequestration whereby ecosystems (e.g., forests, agricultural lands, and wetlands) are maintained, enhanced or manipulated to increase their
Received Date: July 07, 2015

Accepted Date: August 10, 2015

Published Date: August 12, 2015

Citation: Kumar, V. Carbon Sequestration through Reforestation: An Effective Measure to Mitigate the Climate Change. (2015) J Environ Health Sci 1(3): 1-2.

DOI: $10.15436 / 2378-6841.15 . \mathrm{e} 003$

ability to store carbon. Geologic sequestration: There are several types of geologic formations in which $\mathrm{CO}_{2}$ can be stored, including oil reservoirs, gas reservoirs, unminable coal seams, saline formations and shale formations with high organic content. These formations have provided natural storage for crude oil, natural gas, brine and $\mathrm{CO}_{2}$ over millions of years. Geologic sequestration techniques would take advantage of these natural storage capacities. Oceanic sequestration: Oceans absorb, release and store large amounts of $\mathrm{CO}_{2}$ from the atmosphere. There are two approaches for oceanic carbon sequestration which take advantage of the oceans' natural processes. One approach is to enhance the productivity of ocean biological systems (e.g., algae) through fertilization. Another approach is to inject $\mathrm{CO}_{2}$ into the deep ocean ${ }^{[3-6]}$.

\section{Strategies to reduce $\mathrm{CO}_{2}$}

High levels of fossil fuel combustion and deforestation have transformed large pools of fossil carbon (coal and oil) into atmospheric carbon dioxide. Strategies 
aimed at reducing $\mathrm{CO}_{2}$ in the atmosphere include soil carbon sequestration, tree planting, and ocean sequestration of carbon. Other technological strategies to reduce carbon inputs include developing energy efficient fuels, and efforts to develop and implement non-carbon energy sources. All of these efforts combined can reduce $\mathrm{CO}_{2}$ concentrations in the atmosphere and help to alleviate global warming ${ }^{[3,4]}$.

\section{Carbon sequestration in soils}

During the process of photosynthesis, plants assimilate carbon and return some of it to the atmosphere through respiration. The carbon that remains as plant tissue is then consumed by animals or added to the soil as litter when plants die and decompose. The primary way that carbon is stored in the soil is as soil organic matter (SOM). SOM is a complex mixture of carbon compounds, consisting of decomposing plant and animal tissue, microbes (protozoa, nematodes, fungi, and bacteria), and carbon associated with soil minerals. Carbon can remain stored in soils for millennia, or be quickly released back into the atmosphere. Climatic conditions, natural vegetation, soil texture, and drainage all affect the amount and length of time carbon is stored ${ }^{[4,5]}$.

\section{Role of forests in reducing atmospheric carbon}

The forests are important to reduce the $\mathrm{CO}_{2}$ as the forests grow; they store carbon in woody tissues and soil organic matter. The net rate of carbon uptake is greatest when forests are young, and slows with time. Old forests can sequester carbon for a long time but provide essentially no net uptake. When forests are cut, the carbon they contain may be quickly returned to the atmosphere if the woody tissue is burned or converted to products, such as paper, that are short-lived. If the wood is used for construction or furniture, then those products retain carbon during their lifetimes and act as carbon sinks. A post harvest approach that reduces waste and puts most of the wood into long-lived products is an effective strategy to help reduce global atmospheric carbon. However, the net sink for carbon in longlived wood products is still relatively small, so forest cutting ultimately acts to reduce the storage of carbon on land $\mathrm{d}^{[5,6]}$.

\section{Conclusion}

Thus, carbon sequestration is the process of capture and long-term storage of atmospheric carbon dioxide. Afforestation is an important measure to capture the carbon dioxide is naturally from the atmosphere. Therefore, plantation should be done to mitigate the problem of global climate change.

\section{Reference}

1. William H. Schlesinger. Carbon Sequestration in Soils. (1999) Science 284(5423): 2095.

2. Kumar, V., Chopra, A.K. Impact of climate change on biodiversity of India with special reference to Himalayan region-An Overview. (2009) J Appl Nat Sci 1(1): 117-122.

3. Sedjo, R.A., Forest carbon sequestration: some issues for forest investments. (2001) Resources for the Future: Washington, D.C. 1-34.

4. Lal, R., Sequestration of atmospheric $\mathrm{CO}_{2}$ into global carbon pool. (2008) Energy Env Sci 1: 86-100.

5. EPA, Environmental Protection Agency. (2007) Carbon sequestration in agriculture and forestry.

6. EPA. (2015) Carbon Sequestration through Reforestation- a local solution with global implications.
Ommega Online Publishers

Journal Title: Journal of Environment and Health Science (JEHS)

Journal Short Name: J Environ Health Sci
Journal ISSN: 2378-6841

E-mail: environmentalscience@ommegaonline.org

Website: www.ommegaonline.org 